\title{
窒化ケイ素セラミックスの電気的接合
}

江 畑 義弘・香山正憲・岩佐美喜男・木下実

奥田浩司*・高井博史*・西 徳三*

$\left(\begin{array}{c}\text { 大阪工業技術試験所， } 563 \text { 池田市緑丘 1-8-31 } \\ * \text { (株) ダイヘン } 5 \text { 大阪市淀川区田川 2-1-11 }\end{array}\right)$

\section{Electrical Joining of Silicon Nitride Ceramics}

\author{
Yoshihiro EBATA, Masanori KOHYAMA, Mikio IWASA, Makoto KINOSHITA \\ Koji OKUDA*, Hiroshi TAKAI* and Tokumitsu NISHI \\ (Government Industrial Research Institute, Osaka, 8-31, Midorigaoka 1-chome, Ikeda-shi 563 ) \\ * Daihen Corp., 2-1-11, Tagawa, Yodogawa-ku, Osaka-shi 532

\begin{abstract}
Sintered silicon nitride ceramics were joined, employing the joule heating by electric current through the joining paste containing $\mathrm{CaF}_{2}$. The flexual strength of the joint was dependent on the thickness of the joint layer. The thickness was controlled by the time of joule heating. For instance, heating for 10 minutes gave the thickness about 10 to 30 um. This sample showed the maximum strength around $300 \mathrm{MPa}$ up to $800^{\circ} \mathrm{C}$. But the strength decreased rapidly above $900^{\circ} \mathrm{C}$, perhaps because of the softening of the joint layer.

[Received June 28, 1988 ; Accepted September 16, 1988]
\end{abstract}

Key-words : Electrical joining, Silicon nitride, Flexual strength, Joint layer, Reacted layer

\section{1. 緒言}

セラミックスを構造用材料として広範囲に使用するた めには，セラミックス同士又はセラミックスと異種材料 とを接合する技術が必要であり，各種接合方法が提案さ れている(1)-4)。これらの方法のほとんビが被接合体全体 を高温炉中に入れる全体加熱方式であるが，大型，長尺 物の接合に対しては設備上又は母材劣化などの点で問題 であり，局部加熱方式が望まれている.

著者らは局部加熱方式の一つである，通電による ジュール発熱を利用した電気的接合方法について研究を 進めている ${ }^{5), 6)}$. 今回は常圧焼結窒化ケイ素同士の電気 接合を行い, その接合方法, 接合メカ二ズム，及び接合 強度について検討を加えた。

\section{2. 実験}

接合試料には市販の常圧焼結窒化ケイ素 $\left(\mathrm{Si}_{3} \mathrm{~N}_{4}\right)$ を 用いた。そのかさ比重は 3.20 , ヤング率は $290 \mathrm{GPa}$, 硬度は $16 \mathrm{GPa}$, 破壊靶性は $6.0 \mathrm{MN} / \mathrm{m}^{3 / 2}$ である。

接合プロセスの概要を図 1 に示した。 2 個の $\mathrm{Si}_{3} \mathrm{~N}_{4}$ ブ ロック (形状 $15 \times 15 \times 20 \mathrm{~mm}$ ) の接合面 $(15 \times 15 \mathrm{~mm})$ に $\mathrm{CaF}_{2}$ を主体とする接合剤ペーストをスクリーン印刷 法により約 $150 \mu \mathrm{m}$ の厚さに塗布する。これらの接合面 を重ね合せ, 電気接合装置の固定治具にセットし, プロ パンガス炎により $700^{\circ} \sim 800^{\circ} \mathrm{C}$ まで予備加熱する.この 程度の温度になるとペーストの電気抵抗はかなり低下し ているので，電極間に高電圧を印加するとアーク放電を
通してペーストに電流が流れ始める. そのジュール発熱 によってペーストは更に加熱され，十分な導電性を得， 接合に必要な温度に到達することができる，通電電極は 接合長方向で任意パターンの往復移動ができる構造と なっている.均一な加熱が行えるように, 電極移動パ夕一 ンや通電電流值を制御した，通電時間を変化させること による接合状態の変化を調べた。

以上のようにして得られた接合体から $3 \times 4 \times 40 \mathrm{~mm}$

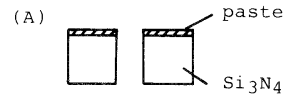

(B)

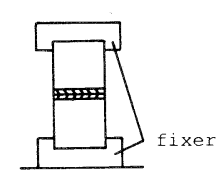

(C)

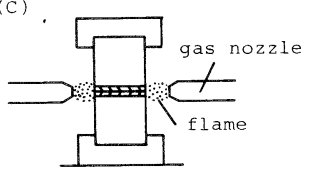

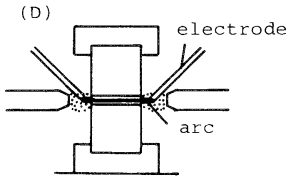

(E)

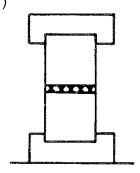

Fig. 1. Process of electrical joining.

(A) coating samples with joining paste by screen printing,

(B) setting up in joining fixer,

(C) preheating by gas flame to $700^{\circ} \sim 800^{\circ} \mathrm{C}$,

(D) joule heating by electric current through joining paste, and then (E) cooling down. 
の試験片を 4 本切り出し, 常温, 高温での強度測定を行っ た. 強度は外スパン $30 \mathrm{~mm}$, 内スパン $10 \mathrm{~mm} の 4$ 点曲げ, クロスヘッドスピード $0.5 \mathrm{~mm} / \mathrm{min} て ゙$ 測定した. 高温 試験は武験片を電気炉内の曲げ治具にセットし, $20^{\circ} \mathrm{C} / \mathrm{min}$ の昇温速度で目的温度まで加熱, 10 分間保持 した.

接合面に垂直な切断面を鏡面研磨し，光学顕微鏡によ る接合状態の観察，EPMA による拡散状態の調査なよ゙ を行った。

\section{3. 結果と考察}

通電時間をいろいろと変化させた場合の, 接合体の常 温 4 点曲げ強度と接合層の厚さの関係を図 2 に示した。 なお，横軸の接合層厚さについては，光学顕微鏡により 測定した武験片の引張応力面での最大最小の範囲を示し ている，通電時間が長くなるとともに接合層厚さは減少 している.接合層が厚すぎると破断は接合層内で起こり， 破面は多数の粒状突起物で覆われていた。また，接合層 が薄すぎるとポアが発生したり，部分的に接合剂が消失

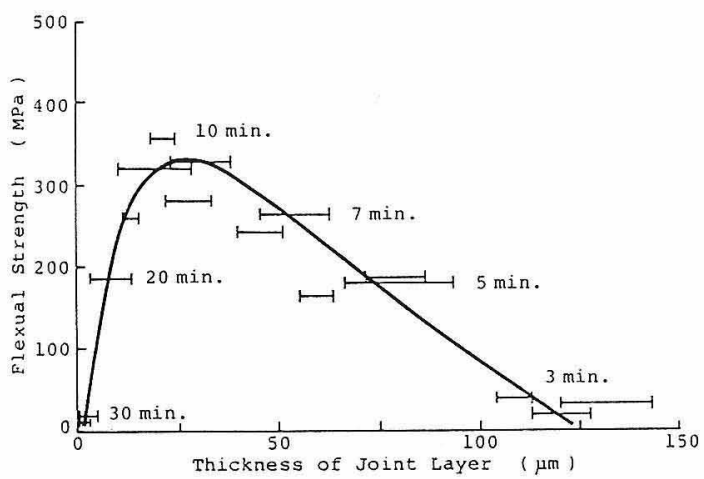

Fig. 2. Relation between thickness of joint layer and flexual strength of joint.

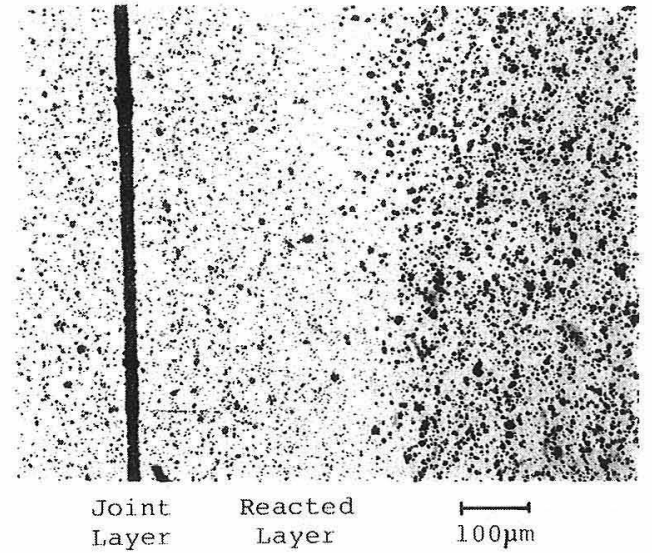

Fig. 3. Optical micrograph of polished surface perpendicular to joint layer of a sample with maximum strength.
して母材面同士が接している状態になっていた。このい ずれの場合も接合強度は極端に低下するので, 通電時間 の調整により接合層厚さを最適に制御する必要がある. 今回の試料については, 10 分程度の通電により接合層 厚さ $10 \sim 30 \mu \mathrm{m}$ が得られ, 強度が最大になることが分 かった.

この最大強度を示す接合武料の切断面の光学䫓微鏡写 真が図 3 である. 初期母材のポアが消失し, よりち密化 したとみられる層（以下，反応層と呼ぶ）が接合層の両 側に幅 300 500 $\mu \mathrm{m}$ にわたって形成されていることが 分かる. この切断面で接合層に垂直に EPMA による元 素分析した結果が図 4 である.ここで縦軸は接合層中央 部の元素量を 1 として規格化している.これによると， 接合剂の成分である $\mathrm{Ca}$ が母材側へ，また $\mathrm{Si}_{3} \mathrm{~N}_{4}$ の焼結 助剤である $\mathrm{Y}, \mathrm{Al}$ が接合層内へ相互に拡散している. この拡散領域が前記反応層領域とほぼ一致していること から，接合剤中の $\mathrm{CaF}_{2}$ 又はそれが酸化された $\mathrm{CaO}$ が 初期母材中のポアを充填することにより反応層が形成さ れるのではないかと推定される.そのメカニズムについ ては現在更に検討中である.

最大常温強度を示す通電時間で作製された接合体につ いて, 4 点曲げ強度の測定温度による変化を母材強度と ともに図 5 に示した。 $800^{\circ} \mathrm{C}$ までは約 $300 \mathrm{MPa}$ でほぼ 常温の強度を維持しているが, $900^{\circ} \mathrm{C}$ 以上になると急激

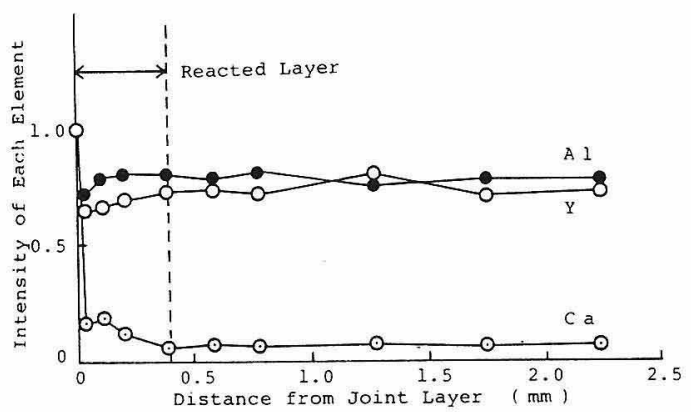

Fig. 4. Line analysis by EPMA around joint layer.

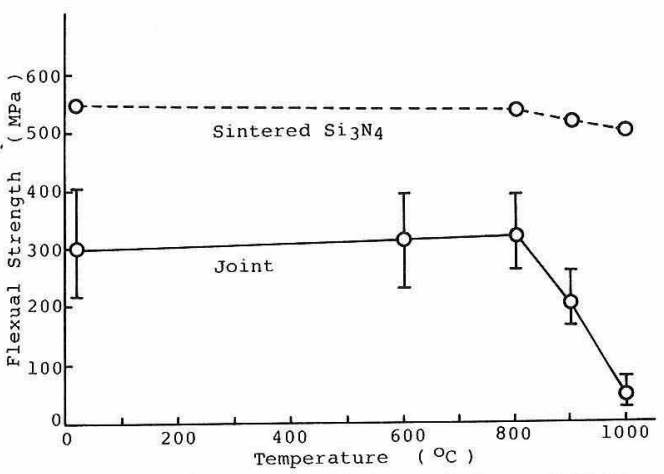

Fig. 5. Flexual strength of joint and sintered $\mathrm{Si}_{3} \mathrm{~N}_{4}$, as functions of temperature up to $1000^{\circ} \mathrm{C}$. 
に低下し， $1000^{\circ} \mathrm{C}$ では $10 \mathrm{MPa}$ 程度まで落ちてしまう。 破断面を観察すると $800^{\circ} \mathrm{C}$ 以下では母材内で破断して いるのに対し, $900^{\circ} \mathrm{C}$ 以上では接合層内で破断している. $900^{\circ} \mathrm{C}$ 以上では応力-歪曲線に塑性域が認められたり, 破断面に糸状になった接合剂が観察されることがあるな ビの点から, 高温強度低下は接合層の軟化が原因である と考えられる. 常温においても，母材強度に比較して， 接合体は完全に母材内で破壊しているにもかかわらず, 約半分の強度となっている。この原因としては, 残留応 力の影響や母材の劣化などが考えられる. 現時点では常 温, 高温強度ともまだいくらか不十分であり, 新たな接 合剂の開発, 接合条件の検討も必要であると思われる.

\section{4. 総 括}

通電によるジュール発熱を利用した電気的接合方法に より, $\mathrm{CaF}_{2}$ 系接合剤を用いて常圧焼結窒化ケイ素同士 の接合を行った，通電時間により接合層の厚さが変化，
接合強度も変化する. この試料では 10 分程度の通電に より, 接合層厚さ $10 \sim 30 \mu \mathrm{m}$ が得られ, 接合強度が最 大となった. $800^{\circ} \mathrm{C}$ までは約 $300 \mathrm{MPa}$ とその強度を維 持するが， $900^{\circ} \mathrm{C}$ 以上になると接合層の軟化により強度 は急激に低下した。

謝辞 本研究は基盤技術研究促進センターの融資を受け て行われたものである．関係者の方々に深甚なる謝意を表する.

\section{文献}

1）江畑儀弘, 木下 実, セラミックス, 18, 17-22 (1983).

2）井関孝善, 機械の研究, 39, 1203-08 (1987).

3) D. N. Coon, R. L. Tallman and R.M. Neilson, $A d v$ anced Ceram. Mater., 3, 154-58 (1988).

4）柴田良昌, 服部善憲, 川村光義, ニューセラミックス, 1, 91-98 (1988).

5）香山正憲，西 徳三，玉利信幸，木下 実，江畑儀弘， 窯協, 94, 1197-200 (1986).

6）速水諒三，機能材料，No. 9, 21-27 (1986). 